\title{
Technical and economic prefeasibility analysis of residential solar PV system in South Kazakhstan
}

\author{
${ }^{1}$ Anuar ASSAMIDANOV, ${ }^{2^{*}}$ Nurbol NOGERBEK, ${ }^{3}$ Luis ROJAS-SOLORZANO, \\ 1, 2, 3 Nazarbayev University, Department of Mechanical Engineering \\ Astana, 010000, Kazakhstan \\ *E-mail: aassamidanov@nu.edu.kz
}

Keywords: Solar photovoltaics (PV), renewable energy, prefeasibility analysis, RETScreen,

\begin{abstract}
In the family of the renewable technologies, photovoltaic (PV) systems today attract considerable attention (Dornfeldt, 2013). However, on-grid PV market is not a profitable sector by itself. It is dependent on the governmental support, which still must stimulate investment with subsidies. Thus, this paper presents the technical and economic prefeasibility analysis of implementing a residential photovoltaic system in South Kazakhstan, using the clean energy project analysis tool RETScreen® V.4. The different systems available for PV cells are considered, however, with the climatic conditions in South Kazakhstan, the study focuses on polycrystalline solar cells (Poly-Si) due to its optimal specifications for the region. Furthermore, local company Astana Solar has implemented a production line of Poly-Si photovoltaic modules using Kazakhstani silicon (Astana Solar, 2012), which could make the project even more attractive to the country.

In the analysis presented, solar resource in South Kazakhstan was estimated using solar radiation data from NASA Surface Meteorology and Solar Energy. For a $6.6 \mathrm{kWp}$ system, installed in the roof of a home, it is found that $8834 \mathrm{MWh}$ of electric energy is exported to the grid in average per year. The suitability of city-level Feed in Tariffs (FITs) to promote solar photovoltaic panels in Kazakhstan is included in the analysis, despite it is very recent and had not been thoroughly examined yet (Ministry of Energy of Kazakhstan, 2014). Several different economic and financial indicators were calculated, such as the Internal Rate of Return (IRR), Net Present Value (NPV), Benefit-Cost (B-C) ratio, Cost of Energy Production (CEP) and Simple Payback (SP). All indicators for all sites explored in South Kazakhstan showed favorable conditions for deployment of the proposed residential solar PV system. The highest IRR of $17.9 \%$, NPV of $\$ 14523$ and B-C ratio of 9.65 was observed in Shymkent and the lowest IRR of $16 \%$, NPV of $\$ 11366$ and B-C ratio of 7.84 was observed in Taraz. Meanwhile, it can be observed that Shymkent got the shortest SP period of 9.9 years and Taraz got the longest payback period of 10.8 years.

The technical and economic analysis shows also that the implementation of an additional $50 \%$ subsidy on total initial cost recently approved, affected very positively the PV-based generation system in southern regions. Therefore, it is found that all southern Kazakhstan is a fertile territory to implement on-grid residential projects.
\end{abstract}

\section{Introduction}

Kazakhstan has substantial influence over energy supply of the world since it owns large natural resources (oil, gas, coal, uranium and other commodities) and a $3 \%$ of the raw material available in the planet. According to statistics (EIA 2013) by 2012 the total power generation capacity of Kazakhstan was approximately $19.5 \mathrm{GW}, 85 \%$ of which was coal-fired power and the remaining $15 \%$ was hydropower. Since 2010 the country decided to import electricity from Kyrgyzstan and Uzbekistan to supply its South regions, since the installed power plants do not reach estimated load and therefore, the consumption of electricity overcomes its production of the country.

Thus, within this framework, the country is currently devoted to development of its renewable energy sector. Kazakhstan has important potential power generation from wind, solar, hydrothermal and small hydro sources. Indeed, the potential energy generation of Kazakhstan exceeds 1 trillion kWh per year which is about 10 times the annual energy consumption in the country at this date (EIA 2013). By the year 2050, the milestone for renewable energy sources is targeted to reach $50 \%$ of total energy consumption (Kazenergy, 2014).

At this moment, apart from partial use of hydro power, the potential for renewable energy is not used sufficiently and a significant generation of electricity may be added by solar power resources according to the economic development targets of the country. For example, 2200-3000 sunny hours per year and $1300-1800 \mathrm{kWh} / \mathrm{m}^{2} /$ year are available due to solar radiation on the country (see Fig. 1 as a reference of the potential in the country) (Kazenergy, 2014). The potential of solar energy in Kazakhstan is estimated at 340 billion tonnes of oil equivalent (toe) annually. However, despite this very attractive scenario for solar power generation this resource is still scarcely used in the country (Energy Charter Secretariat, 2013). 


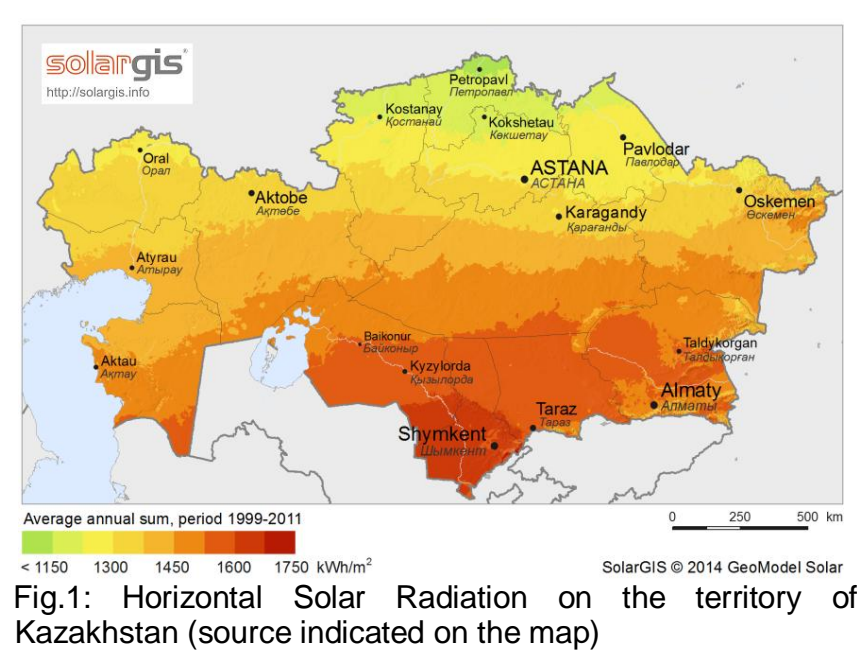

Within these favorable conditions, photovoltaics (PV) today attract considerable attention, but, on-grid PV market is not a profitable sector by itself (Dornfeldt, 2013). It is dependent on the governmental support, which still must stimulate investment with subsidies. In recent years, rapid development in grid-connected building integrated PV systems around the world, mainly in developed countries, is due to the government-initiated renewable energy programs aiming at the development of renewable energy applications and reduction of greenhouse gas emissions (Erge, 2001). For example, in 1990 Germany introduced a "100000-roof program" (Ramana PV, 2005). Japan came with 70000-roof program started in 1994 and lasted the rest of that decade (Yang, 2004). A PV system dissemination program has been very successful in USA, and its 1 million solar-roof initiative is gradually advancing (SSE, 2009). Grid-connected PV systems thus, took off in the mid-to-late 1990's and since then it has been the dominant application in the PV sector.

South Kazakhstan is situated between 42.3 and 44.9 North latitude and 65.5 and 71.4 East longitude with an area of $726 \mathrm{~km}^{2}$, which is an ideal location for solar energy utilization, as previously shown in Fig. 1. Daily solar radiation varies in the range of 4 $4.45 \mathrm{kWh} / \mathrm{m}^{2}$.Thus, densely populated cities like Shymkent, Taraz and Kyzylorda could be electrified by PV on-grid systems using the inexhaustible and pollution free solar energy with locally available technologies. Extra benefits, as supporting a weak grid and reducing $\mathrm{CO}_{2}$ emissions could be also accounted as potential incomes once the program is in mass scale.

Additionally, Kazakhstan has also established at the end of May 2014 a new feed-in tariff (FIT) law - "On Supporting the Use of Renewable Energy Sources". This policy is expected to further increase the installation of grid-connected photovoltaic (PV) systems. Such policy has been implemented and also has been studied in a number of countries such as United Kingdom, Ukraine, Australia, Spain, Taiwan, Germany, Tanzania and other countries, with very positive results(Erge, 2001). As city-level FIT laws for promoting solar photovoltaic panels are very recent and its suitability has not been thoroughly examined yet (Renewable Market Watch, 2014), the fundamental objective of this investigation is to analyze technical and economic prefeasibility of implementing residential photovoltaic system in South Kazakhstan, taking into account the diversity in the southern region and new regulations, as no systematic study has been done to justify the viability for solar power generation in this region to date. As an alternative solution, financial incentives could be obtained if the project is included in the list of priority sectors of the "Business Road Map 2020" that is one of the "DAMU Entrepreneurship Development Fund" projects. This initiative has as its main goal to provide governmental support for projects of non-primary sectors of economy (Halyk bank, 2013).

\section{Solar Energy Resource Potential}

\section{II.1. Theoretical Potential}

The average sunny hours per day and monthly solar radiation were found, based on an average solar radiation data taken from NASA for 3 widespread locations in south Kazakhstan available through RETScreen workbench tool (SSE, 2009). According climate database NASA data, South Kazakhstan receives approximately 1185 GWh of solar energy every year, which is more than 30 times higher than the current electricity generation in those cities. However, in the course of exploitation, constraints such as land use, geographical area and climate are encountered. Theoretically, a great potential for developing solar power system is considered when the average daily radiation is above $4 \mathrm{Wh} / \mathrm{m}^{2} /$ day in average per year (Energy Charter Secretariat, 2013).

Tab. 1: Average daily solar radiation in south Kazakhstan

\begin{tabular}{|c|c|c|c|c|}
\hline City Name & $\begin{array}{c}\text { Elevation } \\
(\mathbf{m})\end{array}$ & $\begin{array}{c}\text { Latitude } \\
\text { (degree) }\end{array}$ & $\begin{array}{c}\text { Longitude } \\
\text { (degree) }\end{array}$ & $\begin{array}{c}\text { Radiation } \\
(\mathbf{N A S A}) \\
\left(\mathbf{k W h} / \mathbf{m}^{2} / \text { day }\right)\end{array}$ \\
\hline Kyzylorda & 130 & 44.9 & 65.5 & 4.21 \\
\hline Taraz & 655 & 42.9 & 71.4 & 4 \\
\hline Shymkent & 604 & 42.3 & 69.7 & 4.45 \\
\hline
\end{tabular}

\section{II.2. Technical Potential}

There is a clear potential market for grid-connected PV systems in the densely populated urban and electrified areas, i.e., for solar home systems are central-grid households. Locally available PV system specification and financial assumptions, according to current conditions and trends in Kazakhstan, were entered in the RETScreen workbench. Then, it was calculated the expected generated electricity by the solar power home-system on a yearly basis under different scenarios of Feed-in-Tariff (FIT) in place.

Local company Astana Solar is currently producing Poly-Si photovoltaic modules using Kazakhstani silicon (Astana Solar, 2012). The efficiency of the PV array is about $16 \%$ and Astana Solar guarantees that its products have a lifetime of at least 25 years. Tab. 2 shows the detail technical specification of the solar panel that was used in this study. 
Tab. 2: Technical specification of solar PV panels used in the analysis

\begin{tabular}{|l|c|}
\hline Item & Specification \\
\hline Manufacturer & Astana Solar LLP \\
\hline PV module type & Multi-Si \\
\hline Module number & $16 \%$ \\
\hline Efficiency & $220 \mathrm{Wp} / \mathrm{module}$ \\
\hline Rated Power (Pmax) & $30 \quad(6.6 \mathrm{kWp}$ array) \\
\hline Number of modules & $29.4 \mathrm{~V}$ \\
\hline Voltage at Pmax & $7.5 \mathrm{~A}$ \\
\hline Current at Pmax & $8.3 \mathrm{~A}$ \\
\hline Short circuit current & 36.5 \\
\hline Open circuit voltage & 1.64 \\
\hline Frame area & $19.5 \mathrm{~kg}$ \\
\hline Dimension & $1.649 \mathrm{~m} \times 0.992 \mathrm{~m} \times 0.40 \mathrm{~m}$ \\
\hline Weight & \\
\hline
\end{tabular}

\section{Economic Viability of grid-connected solar PV system}

\section{III.1. Global solar radiation}

Due to limited available solar radiation data in Kazakhstan, a NASA data set for the period from 1985 to 1995 was used. 10-year averaged NASA global solar radiation data from 3 widespread south Kazakhstan locations (Tab. 1) were used for the technical-economic analysis of grid-connected solar PV system (SS, 2009).

\section{III.2. Proposed 6.6 kW solar PV system and financial assumption}

The proposed solar PV grid-connected system is an array with a total power capacity of $6.6 \mathrm{kWp}$ consisting of 30 fixed panels with a total area of $49.2 \mathrm{~m}^{2}$ (Tab. 2). The size of the array was chosen such that it fits the estimated roof area of a south Kazakhstani residence. The solar array system costs 2354 US $\$ / k W p$ (Astana Solar, 2012). The PV array is faced toward south and is inclined at a $42^{\circ}$ angle, equal to the site latitude. Zero azimuth angles was taken for all the studied locations. DC into AC string inverters were utilized in the proposed system with a total capacity of $5.94 \mathrm{~kW}$ with an efficiency of $90 \%$. The cost of the inverter is 220 US $\$$ kWp (Astana Solar, 2012). The economic feasibility analysis was performed using data on initial costs associated with the implementation of the proposed system, and prevailing loan interest, inflation and energy escalation rates prevailing in the country.

In this study, project life is assumed to be 25 years. As this project is in prefeasibility level calculation of the total cost has been simplified. With respect to total expenses, Development represents 5\%, and Engineering $15 \%$ of the total cost. Annual O\&M is about $1 \%$ of total initial cost. Cost of the construction phase would be $75 \%$ of the total initial expenses. Tab. 3 provides some details and assumptions considered for the whole financial analysis, based on current market and financial situation in the country (The National Bank of Kazakhstan, 2014). Feed-in-Tariff (FIT) is specially included according to new government policies starting on the generation of power from renewable sources, in place since 2014 (Ministry of Energy of Kazakhstan, 2014). Therefore in this analysis the FIT will be assumed as 191.4 \$/MWh.

Tab. 3: Financial assumption and data for the study

\begin{tabular}{|l|c|}
\hline Parameter & Value (currency at year 2014 value) \\
\hline Solar panel & 2354 US $\$ / k W p$ \\
\hline Inverter cost & 220 US\$ $/ \mathrm{kWp}$ \\
\hline Annual O\&M & US\$168 \\
\hline Inflation rate & $5.4 \%$ \\
\hline FIT & 191.4 US\$/MWh \\
\hline $\begin{array}{l}\text { FIT escalation } \\
\text { rate }\end{array}$ & $8 \%$ \\
\hline Debt ratio & $80 \%$ \\
\hline $\begin{array}{l}\text { Debt interest } \\
\text { rate }\end{array}$ & $17 \%$ \\
\hline Debt term & 10 years \\
\hline Project life & 25 years \\
\hline
\end{tabular}

\section{III.3. Results}

\section{III.3.1. Electricity generation}

The amount of equivalent DC electrical energy actually generated by the proposed $6.6 \mathrm{kWp}$ solar grid-connected system to the utility was calculated for all 3 locations in the annual electricity production. The highest electricity annual production was obtained in Shymkent with about 8.9 MWh. The lowest production was obtained in Taraz with an annual electricity generation of $8.1 \mathrm{MWh}$. For an average city in south Kazakhstan, an estimate of $6.1 \mathrm{MWh} /$ year of electricity can be delivered using the proposed PV system.

\section{III.3.2.Economic feasibility indicators}

The decision making indicators from the financial analysis throughout the PV system lifetime are presented as follows (see also Tab. 4):

Internal Rate of Return (IRR): The maximum IRR of $17.9 \%$ was observed in Shymkent, while the minimum IRR of $9.9 \%$ was observed in Taraz. Therefore, an IRR of $16 \%$ can be obtained in an average city in south Kazakhstan.

Net present Value (NPV): The highest NPV value was about $\$ 14523$ for Shymkent and the lowest was about $\$ 11366$ for Taraz.

Benefit-Cost (B-C) ratio: The B-C ratio was found to be the highest (9.65) in Shymkent, while the lowest (7.84) was found in Kyzyl-orda.

Simple Payback (SP): It was found that on an average, a SP of about 9.9 years can be obtained from any location of south Kazakhstan. 
Tab. 4: Economic indicators for 6.6 - kWp solar PV system for 3 locations, south Kazakhstan.

\begin{tabular}{|l|l|l|l|}
\hline \multicolumn{1}{|c|}{$\begin{array}{l}\text { Financial } \\
\text { Results }\end{array}$} & Shymkent & Kyzylorda & Taraz \\
\hline $\begin{array}{l}\text { IRR on } \\
\text { equity }\end{array}$ & $17.9 \%$ & $17.3 \%$ & $16 \%$ \\
\hline $\begin{array}{l}\text { Net Annual } \\
\text { Income }\end{array}$ & $\$ 1191$ & $\$ 1078$ & $\$ 973$ \\
\hline $\begin{array}{l}\text { Net Present } \\
\text { Value }\end{array}$ & $\$ 14523$ & $\$ 13741$ & $\$ 11366$ \\
\hline $\begin{array}{l}\text { Payback } \\
\text { Period }\end{array}$ & 9.9 & 10.2 & 10.8 \\
\hline $\begin{array}{l}\text { Benefit-Cost } \\
\text { Ratio }\end{array}$ & 9.65 & 9.03 & 7.84 \\
\hline
\end{tabular}

\section{III.4. Sensitivity analysis}

A Monte Carlo analysis, based on a sample of 500 scenarios, allowed to find the probable outcomes under known uncertainty of input parameters. In this study, a $\pm 10 \%$ uncertainty is assumed for the Initial Cost, O\&M, FIT and debt ratio, while an uncertainty of $\pm 20 \%$ was assumed for debt interest rate and debt term. Since debt parameters vary widely with current Kazakhstani bank services which depend on project scope.

The impact tornado graph, presented in Fig. 2, shows how much of the variation in the financial parameter can be explained by variation in each input parameter. The impact analysis demonstrates that the changes in NPV and IRR are largely due to variation of FIT, followed by initial cost and, debt interest rate in about the same level of importance, as shown in Fig. 2.

Since residential solar PV has no analogies within the country, this analysis should be used as a support mechanism to stimulate implementing this types of projects in the country.
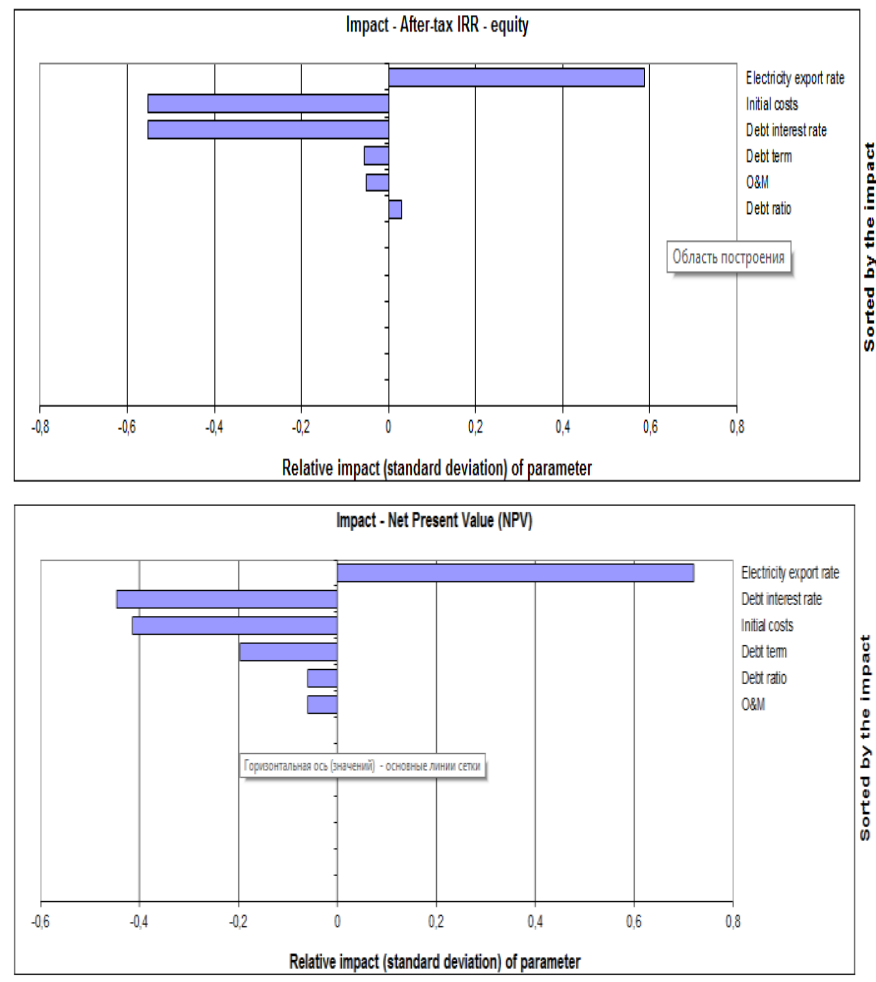

Fig. 2: Impact results of NPV and IRR for Shymkent
According to these results, an even better solution for Shymkent could be obtained if the project is included in the list of priority sectors of the "Business Road Map - 2020" that is one of the "DAMU Entrepreneurship Development Fund" projects. This initiative has as its main goal to provide governmental support for projects of non-primary sectors of economy. In this particular case, if implemented, the government may subsidize $50 \%$ of the initial cost of project and the remainder is taken completely as loan $(100 \%$ debt ratio; i.e., no equity needed) from the bank by the owner at $7 \%$ of debt interest rate (Halyk bank, 2013). As it can be observed in Tab. 5, there are significant differences in financial results when government provides subsidies. All financial parameters indicate that government subsidy is a very beneficial approach promoting residential solar PV.

Tab. 5: Comparison of financial viability

\begin{tabular}{|l|l|l|}
\hline Financial Results & $\begin{array}{c}\text { Residential PV } \\
\text { in Shymkent }\end{array}$ & $\begin{array}{c}\text { Residential PV in } \\
\text { Shymkent with } \\
\text { government } \\
\text { subsidy }\end{array}$ \\
\hline IRR on equity & 17.9 & 18.1 \\
\hline Net Annual Income & $\$ 1191$ & $\$ 2523$ \\
\hline Net Present Value & $\$ 14523$ & $\$ 26220$ \\
\hline Payback Period & 9.9 & 5.5 \\
\hline Benefit-Cost Ratio & 9.65 & 4.12 \\
\hline
\end{tabular}

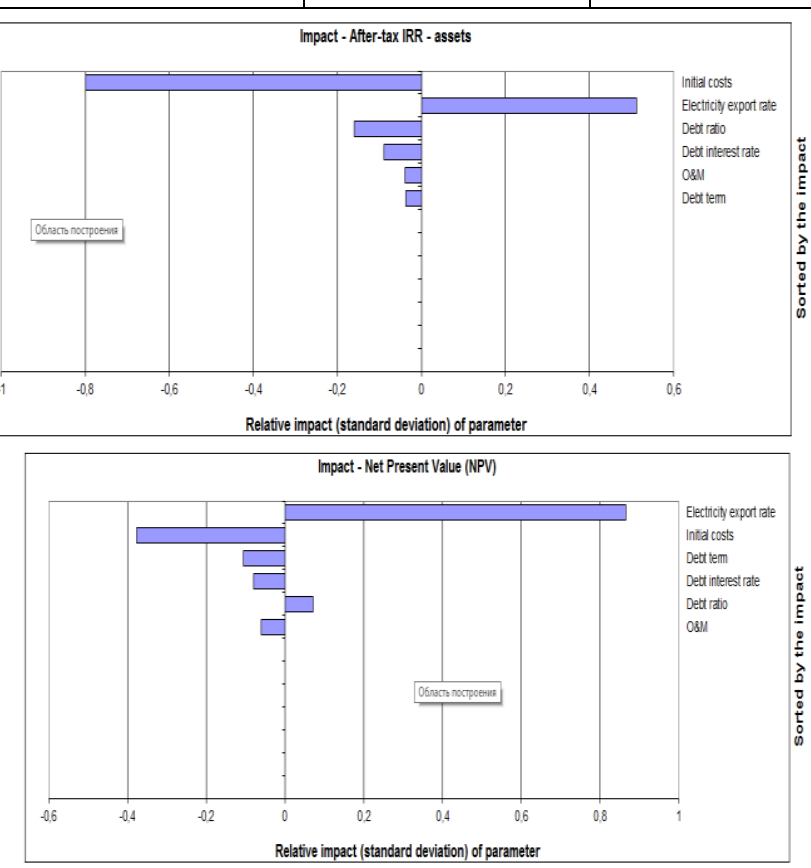

Fig. 3: Impact results of NPV and IRR for Shymkent with government support

\section{Conclusions}

This study analyses the technical and economic potential of solar photovoltaic-grid connected system in south Kazakhstan. The technical assessment considers several locally manufactured PV systems. The study focuses on polycrystalline solar cells (poly-Si) due to its optimal financial and technical specifications for south Kazakhstan climatic conditions. 
The analysis determined that with a $6.6 \mathrm{kWp} \mathrm{PV}$ array it is possible to generate and export to the grid a minimum of 8.9 MWh in Taraz, and a maximum of 9.1 $\mathrm{MWh}$ in Shymkent. Financial indicators from the lifecycle cost analysis for all sites showed favorable condition for development of the proposed residential solar PV system in South Kazakhstan, proving that on a lifetime frame of 25 years, the application of solar PV for residential grid-connected systems is quite feasible financially.

A new policy, in conjunction with the Feed-in Tariff (FIT) is envisioned from the study. The economic analysis suggests that a subsidy of $50 \%$ of total initial cost should be considered to maximize the advantage for the residential owner of the PV-system in sourthern regions. This will also help to support the weak grid in the region, under constant threat during peak load hours.

\section{References}

Astana Solar, About company. Retrieved November 2, 2014, from: http://www.astanasolar.kz/en/about-us.

Dornfeldt, M., The future of the Kazakh energy sector and the Kazakhstan 2050 Strategy. Retrieved November 2, 2014, from 18th REFORM Group Meeting http://www.polsoz.fu-berlin.de/polwiss/forschung/systeme/ffu/ veranstaltungen/termine/downloads/13_salzburg/Dornfeldt-S alzburg-2013.pdf (2014).

Energy Charter Secretariat, Investment Climate and Market Structure Review in the Energy Sector of KAZAKHSTAN. Retrieved November 3, 2014, from Energy Charter: http://www.encharter.org/fileadmin/user_upload/Publications/ Kazakhstan_ICMS_2013_ENG.pdf (2013).

Erge, T., Hoffmann, U., Kiefer, K. The German experience with grid-connected PV-systems., 2001. Solar Energy:704 79-87.

IEA, World Energy Outlook. Retrieved November 3, 2014, from International Energy Statistics: http://www.eia.gov/countries/analysisbriefs/Kazakhstan/kaza khstan.pdf (2013).

Kazenergy, Green Energy of Kazakhstan. Retrieved November 2, 2014, from: http://www.kazenergy.com/ru/5-49-2011/3445-green-energyof-kazakhstan.html (2014).

Ramana PV. SPV technology dissemination - A global review. Solar photovoltaic systems in Bangladesh, experiences and opportunities, Dhaka, Bangladesh: The University Press Limited, 119-38. ( 2005)

Renewable Market Watch, Kazakhstan Solar and Wind Power Markets. New feed-in tariffs and very good opportunities for 2014. Retrieved November 2, 2014, from: http://renewablemarketwatch.com/news-analysis/136-kazakh stan-solar-and-wind-power-market-new-feed-in-tariffs-and-ve ry-good-opportunities-for-2014.

SSE, "Surface meteorology and Solar Energy, A renewable energy resource web site, sponsored by NASA's Earth Science Enterprise Program. Retrieved October 29, 2014, http://eosweb.larc.nasa.gov/sse.

Yang H., Zheng G., Lou C., An D., Burnett J.. Grid-connected building-integrated photovoltaics: a Hong Kong case study. Solar Energy; (2004)

The National Bank of Kazakhstan, Loan market. Retrieved January 24, 2015, from:

http://www.nationalbank.kz/?docid=158\&switch=english 